\title{
The Role Concept in Corporate Branding and Stakeholder Management Reconsidered: Are Stakeholder Groups Really Different?
}

\author{
Lars Fiedler \\ Department of Marketing Management, HHL-Leipzig Graduate School \\ of Management, Leipzig, Germany \\ Manfred Kirchgeorg \\ Department of Marketing Management, HHL-Leipzig Graduate School \\ of Management, Leipzig, Germany
}

\begin{abstract}
In many cases, research in corporate branding, stakeholder management and also corporate reputation management takes on a role concept without testing or probing it. This paper seeks to analyze if customers, employees, shareholders and journalists - as important corporate stakeholders - are truly distinguishable target groups for corporate branding and stakeholder management. Using discriminant and factor analyses, this study found strong support for the role concept, in particular, concluding that some stakeholder attributes are more appropriate for generic, nonspecific branding and marketing approaches while several other attributes are better suited to stakeholder-specific targeting or positioning strategies.

Corporate Reputation Review (2007) 10, 177-188. doi:10.1057/palgrave.crr.1550050
\end{abstract}

KEYWORDS: corporate branding; role concept; stakeholder management; stakeholder groups; discriminant analysis; factor analysis

\section{INTRODUCTION AND PURPOSE OF THE STUDY}

In recent years, a growing body of publications about corporate branding (Balmer, 2001; de Chernatony, 2002; de Chernatony and Riley, 1998; Schultz and de Chernatony, 2002; Griffin, 2002: Burt and Sparks, 2002) has emerged, based on the conceptual underpinnings of classical brand management literature (Aaker and Joachimsthaler, 2000; Keller, 2003). Because corporate branding is increasingly considered an important independent field of research, these contributions are gaining a wider perspective in the context of product branding (Aaker, 2004; Keller and Aaker, 1997). Some authors even claim a generic shift of emphasis from line branding to corporate branding (Balmer, 1995; Harris and de Chernatony, 2001). A psychological, perception-based interpretation enables us to define a corporate brand as 'a distinctive image (or imaginary picture) of a corporation, tightly anchored in the psyche of the stakeholder, that influences the behavior of stakeholders' (Meffert and Bierwirth, 2005: 144). Corporate branding is the management of the corporate brand. It is a process that includes goal-oriented planning, coordination and control of all activities of the corporate brand. Unlike product branding, it focuses not only on the consumer, but also on all relevant stakeholders of a corporation.

This psychological interpretation highlights the close connection of corporate
Corporate Reputation Review Vol. 10, No. 3, pp. 177-188 (C) 2007 Palgrave Macmillan Ltd, 1363-3589 $\$ 30.00$ 
branding to the stakeholder approach (Clarke, 1998; Jones, 1995; Walker and Marr, 2001). The stakeholder approach has moved beyond a once-simpler shareholder orientation to advocate the consideration of a wide range of additional stakeholders in the corporate strategy such as employees, business partners and special interest groups or journalists. A well-accepted definition of a stakeholder is 'any group or individual who can affect or is affected by the achievement of an organization's purpose' (Freeman, 1984: $25)$. Research in the field of internal marketing (Bergstrom et al., 2002; George, 1990), employer branding (Berthon et al., 2005), investor relations (Hägg and Preiholt, 2004) or public relations are just a few examples of the extensive efforts to approach different stakeholder groups specifically in order to achieve favorable positioning of the corporate brand in the minds of the targeted stakeholder groups. These multi-stakeholder judgments about any specific organization also impinge upon such areas of research as corporate reputation management, stakeholder management and corporate branding.

Interestingly, all these approaches implicitly assume that the role-based stakeholder concept relies on homogeneous attributes within groups despite simultaneous heterogeneous attributes that differentiate groups. Homogeneity implies that 'a person's role is a pattern or type of social behaviour which seems situationally appropriate to him in terms of the demands and expectations of those in his group' (Sargent, 1951: 360) In every society, people hold or occupy certain positions (as employer, shareholder, etc) or are accorded particular status (mother, father, etc). Socially prescribed duties or functions are assigned to every social position. The role concept posits that people (eg, journalists or shareholders) who assume similar social roles share similar patterns of social behavior and attributes within their respective groups (Coutu, 1951: 180) and see the review of definitions of role of Gross et al. (1958). Few researchers express doubts that they can easily differentiate groups: to do otherwise would admit the need for more detailed investigation of stakeholder groups in order to perform specific targeting or positioning. Nevertheless, some articles have begun to tackle the issue (Harrison and Freeman 1996; Winn, 2001).An exceptional article by Wolfe and Putler (2002) challenges the views on role concept that appear in the bulk of stakeholder literature. The authors criticize what they regard as unreflective assumptions about stakeholder group attributes as they relate to group members' priorities, opinions, personal values and sociodemographics. They propose a segmentation-oriented alternative (Wolfe and Putler, 2002). Another approach touching upon this problem differentiates among (1) micro associations that have to be addressed specifically on the stakeholder group level, (2) meta associations that allow a comprehensive approach to all stakeholders and (3) macro associations that reflect the aggregated overall picture of a corporation (Hermann, 2005).

The purpose of this paper is, thus, to analyze distinguishing attributes of different stakeholder groups in order to test frequent assumptions about the role concept. The basic hypothesis we will analyze is that significant differences exist among stakeholder groups, thereby supporting the role concept of stakeholder groups. A further test is to determine which stakeholder group attributes best discriminate among different groups. These results will enable marketing practitioners to position their corporate brands generically, without having to consider group particulars. In other cases, they would need to target single stakeholder groups with specific communication activity in order to specifically position a corporate brand.

\section{RESEARCH METHODOLOGY}

The study concentrates on the corporate brand of a leading and well-known German service corporation noted in DAX 30, the 
personal value structures could prove useful

German share index. Four major stakeholder groups such as customers, employees, shareholders and journalists comprise the subjects of this study, based on their importance according to prior research (Walker Information Global Network, 1999). We screened approximately 100,000 German citizens by e-mail to determine to which of the stakeholder groups of the corporation they belonged. A specific media database generated the necessary contact data for journalists.

After grouping the respondents into different stakeholder categories, we developed and distributed four types of questionnaires to a random sample of respondents from each stakeholder group. The survey consisted of a generic part that was identical for all groups and a specific part for customers, employees, shareholders and journalists, respectively. The generic part of the survey served as a control to compare the four stakeholder groups. Questionnaire items were grouped into categories that would reflect attributes or behavioral constructs widely used in marketing research. The forms included questions about the importance of affective and cognitive associations of the corporate brand, the evaluation of affective and cognitive associations of the corporate brand, the corporation's reputation, its media exposure and the respondent's personal value system. In marketing, the importance of brand associations (Brown, 1998; Brown and Dacin, 1997) may be helpful in differentiating stakeholder groups based on their priorities and expectations - and to position the corporation accordingly. A corporation's reputation (Fombrun and van Riel, 1997; Fombrun and Gardberg, 2000; Wiedmann, 2002) as well as evaluations of its corporate brand image might be used for determining precise positioning in the competitive landscape. In order to tailor communication strategies to specific stakeholder groups, knowledge about varying media exposure could be very helpful. Finally, deeper knowledge about in developing positioning strategies. All responses were measured on standard, fivepoint Likert scales. The survey resulted in 789 stakeholder responses from four groups (296 customers, 116 employees, 276 shareholders and 101 journalists).

Discrimination analysis was the method employed to identify the distinguishing attributes of the four stakeholder groups. This statistical method has a long history (Fisher, 1936) and is generally utilized to analyze whether groups differ significantly and which variables discriminate between members of two or more groups by building an index to separate the observed groups based on the values of their different attributes (Lehmann et al., 1998):

$$
f=w_{1} x_{1}+w_{2} x_{2}+w_{3} x_{3}+\ldots+w_{k} x_{k}
$$

where $x_{1}, x_{2}, x_{3} \ldots x_{k}$ are measured attributes (variables) of stakeholders, $f$ the variable for the discriminant function and $w_{1}, w_{2}, w_{3} \ldots w_{k}$ the weights (discriminant coefficient) of the $k$ th characteristic in discriminating between the stakeholder groups.

The objective of this output analysis is to reveal those attributes that best explain how we can distinguish and weight each group (ie, its discriminant function based on its discriminant loading). We test the significance of the functions and variables primarily using Wilks' $\lambda$ and the $F$-statistic (Aaker et al., 2004). It is assumed that each case is independent. Our research design also allows for group membership to be regarded as mutually exclusive and collectively exhaustive. More problematic are the expectations that predictor variables will have a multivariate normal distribution and that within-group variancecovariance matrices will be equal across groups. Even though the method is remarkably robust against certain violations of assumptions (Lehmann et al., 1998), we make further efforts to ameliorate these problems. 
As a Box's $M$-test (Lattin et al., 2003: 443f.) of several outputs shows, there is a potential problem with assessing the heterogeneity of the covariance matrices when separate-group covariance matrices are used to test whether a classification would change significantly. In this instance, the results of the Box's $M$-test are probably an effect of the size of the data file. Hence, our data input can be considered to have met the general assumptions and requirements of the method. In order to avoid the problem of correlated independent variables, we conducted factor analyses of the discriminating attributes (Stewart, 1981) and consequently, performed the discriminant analyses once again, with a reduced number of factor values.

\section{EMPIRICAL RESULTS OF THE DISCRIMINANT ANALYSIS}

First, we performed discriminant analyses using full sets of the characterizing variables

Table 1: Result of the discriminant analysis with full sets of variables

\begin{tabular}{|c|c|c|c|c|c|c|c|c|}
\hline \multirow[t]{2}{*}{ Discriminating attributes } & \multirow{2}{*}{$\begin{array}{l}\text { No. of } \\
\text { items }\end{array}$} & \multirow[t]{2}{*}{ Function } & \multicolumn{3}{|l|}{ Eigenvalues } & \multicolumn{2}{|c|}{ Wilks' Lambda } & \multirow{2}{*}{$\begin{array}{l}\text { Correct } \\
\text { classification (\%) }\end{array}$} \\
\hline & & & Eigenvalue & $\begin{array}{l}\% \text { of } \\
\text { variance }\end{array}$ & $\begin{array}{l}\text { Canonical } \\
\text { correlation }\end{array}$ & $\begin{array}{l}\text { Wilks' } \\
\text { Lambda }\end{array}$ & Chi Square & \\
\hline $\begin{array}{l}\text { Importance of affective } \\
\text { associations }\end{array}$ & 10 & $\begin{array}{l}1^{\mathrm{a}} \\
2\end{array}$ & $\begin{array}{l}2.377^{\mathrm{b}} \\
0.243^{\mathrm{b}}\end{array}$ & $\begin{array}{r}90.2 \\
9.2\end{array}$ & $\begin{array}{l}0.839 \\
0.442\end{array}$ & $\begin{array}{l}0.235 \\
0.793\end{array}$ & $\begin{array}{c}1128.9^{\star} \\
180.8^{\star}\end{array}$ & 61.0 \\
\hline $\begin{array}{l}\text { Importance of cognitive } \\
\text { associations }\end{array}$ & 10 & $\begin{array}{l}1^{\mathrm{a}} \\
2\end{array}$ & $\begin{array}{l}3.008^{\mathrm{b}} \\
0.620^{\mathrm{b}}\end{array}$ & $\begin{array}{l}81.3 \\
16.8\end{array}$ & $\begin{array}{l}0.866 \\
0.619\end{array}$ & $\begin{array}{l}0.144 \\
0.576\end{array}$ & $\begin{array}{c}1513.5^{\star} \\
430.6^{\star}\end{array}$ & 69.5 \\
\hline $\begin{array}{l}\text { Importance of affective } \\
\text { and cognitive associations }\end{array}$ & 20 & $\begin{array}{l}1^{\mathrm{a}} \\
2\end{array}$ & $\begin{array}{l}4.161^{\mathrm{b}} \\
0.833^{\mathrm{b}}\end{array}$ & $\begin{array}{l}81.2 \\
16.3\end{array}$ & $\begin{array}{l}0.898 \\
0.674\end{array}$ & $\begin{array}{l}0.093 \\
0.482\end{array}$ & $\begin{array}{c}1832.5^{\star} \\
563.9^{\star}\end{array}$ & 74.4 \\
\hline $\begin{array}{l}\text { Evaluation of affective } \\
\text { associations }\end{array}$ & 10 & $\begin{array}{l}1^{\mathrm{a}} \\
2\end{array}$ & $\begin{array}{l}0.324^{\mathrm{b}} \\
0.196^{\mathrm{b}}\end{array}$ & $\begin{array}{l}60.5 \\
36.6\end{array}$ & $\begin{array}{l}0.494 \\
0.405\end{array}$ & $\begin{array}{l}0.622 \\
0.823\end{array}$ & $\begin{array}{l}366.9^{\star} \\
150.2^{\star}\end{array}$ & 51.9 \\
\hline $\begin{array}{l}\text { Evaluation of cognitive } \\
\text { associations }\end{array}$ & 10 & $\begin{array}{l}1^{\mathrm{a}} \\
2\end{array}$ & $\begin{array}{l}0.295 \\
0.129\end{array}$ & $\begin{array}{l}57.4 \\
25.1\end{array}$ & $\begin{array}{l}0.478 \\
0.339\end{array}$ & $\begin{array}{l}0.627 \\
0.812\end{array}$ & $\begin{array}{l}362.7^{\star} \\
161.5^{\star}\end{array}$ & 53.5 \\
\hline $\begin{array}{l}\text { Evaluation of affective and } \\
\text { cognitive associations }\end{array}$ & 20 & $\begin{array}{l}1^{\mathrm{a}} \\
2\end{array}$ & $\begin{array}{l}0.488^{\mathrm{b}} \\
0.328^{\mathrm{b}}\end{array}$ & $\begin{array}{l}52.9 \\
35.6\end{array}$ & $\begin{array}{l}0.572 \\
0.497\end{array}$ & $\begin{array}{l}0.457 \\
0.680\end{array}$ & $\begin{array}{l}599.2^{\star} \\
295.0^{\star}\end{array}$ & 62.9 \\
\hline Corporate reputation & 5 & $\begin{array}{l}1^{\mathrm{a}} \\
2\end{array}$ & $\begin{array}{l}0.220^{\mathrm{b}} \\
0.086^{\mathrm{b}}\end{array}$ & $\begin{array}{l}65.4 \\
25.6\end{array}$ & $\begin{array}{l}0.425 \\
0.282\end{array}$ & $\begin{array}{l}0.733 \\
0.894\end{array}$ & $\begin{array}{r}242.4^{\star} \\
87.4^{\star}\end{array}$ & 46.6 \\
\hline Media exposure & 12 & $\begin{array}{l}1^{\mathrm{a}} \\
2\end{array}$ & $\begin{array}{l}0.773^{\mathrm{b}} \\
0.237^{\mathrm{b}}\end{array}$ & $\begin{array}{l}74.1 \\
22.7\end{array}$ & $\begin{array}{l}0.660 \\
0.438\end{array}$ & $\begin{array}{l}0.441 \\
0.782\end{array}$ & $\begin{array}{l}630.5^{\star} \\
189.5^{\star}\end{array}$ & 59.9 \\
\hline Value system & 15 & $\begin{array}{l}1^{\mathrm{a}} \\
2\end{array}$ & $\begin{array}{l}0.818 \\
0.046\end{array}$ & $\begin{array}{r}90.3 \\
5.1\end{array}$ & $\begin{array}{l}0.671 \\
0.210\end{array}$ & $\begin{array}{l}0.505 \\
0.917\end{array}$ & $\begin{array}{r}529.2^{\star} \\
66.8^{\star}\end{array}$ & 55.6 \\
\hline All above attributes & 72 & $\begin{array}{l}1^{\mathrm{a}} \\
2\end{array}$ & $\begin{array}{l}5.709 \\
1.245\end{array}$ & $\begin{array}{l}76.9 \\
16.8\end{array}$ & $\begin{array}{l}0.922 \\
0.745\end{array}$ & $\begin{array}{l}0.045 \\
0.303\end{array}$ & $\begin{array}{c}2262.0^{\star} \\
872.5^{\star}\end{array}$ & 83.0 \\
\hline
\end{tabular}

${ }^{a}$ For Wilks' Lambda, this line represents the test of functions 1 to 2

${ }^{b}$ First three canonical discriminant functions were used in the analysis

$\star$ Significant at $1 \%$ level 
Table 2: Overview about results of all factor analyses

\begin{tabular}{|c|c|c|c|c|c|c|c|c|c|}
\hline Category & Factor $1(4)^{a}$ & $E V^{b}$ & $\begin{array}{l}\% \text { of } \\
\text { Variance }\end{array}$ & Factor $2(5)^{a}$ & $E V^{b}$ & $\begin{array}{l}\% \text { of } \\
\text { Variance }\end{array}$ & Factor 3 & $E V^{b}$ & $\begin{array}{l}\% \text { of } \\
\text { Variance }\end{array}$ \\
\hline $\begin{array}{l}\text { Importance of } \\
\text { affective associations }\end{array}$ & Liking and fit & 2.8 & 27.9 & $\begin{array}{r}\text { Clear and } \\
\text { different }\end{array}$ & 2.6 & 54.1 & - & & \\
\hline $\begin{array}{l}\text { Importance of cognitive } \\
\text { associations }\end{array}$ & Sustainability & 4.2 & 4.9 & Leadership & 2.4 & 65.9 & - & & \\
\hline $\begin{array}{l}\text { Evaluation of affective } \\
\text { associations }\end{array}$ & Liking and fit & 3.6 & 35.5 & $\begin{array}{r}\text { Clear and } \\
\text { different }\end{array}$ & 2.0 & 55.0 & - & & \\
\hline $\begin{array}{l}\text { Evaluation of } \\
\text { cognitive associations }\end{array}$ & Sustainability & 2.9 & 29.3 & Leadership & 2.3 & 52.7 & - & & \\
\hline Reputation & Reputation & 3.3 & 65.2 & - & & & - & & \\
\hline Media exposure & Mass Media & 2.2 & 18.6 & Specific media & 2.0 & 35.3 & Mail & 1.2 & 45.0 \\
\hline \multirow[t]{2}{*}{ Values } & Living standards & 1.4 & 9.4 & $\begin{array}{l}\text { Knowledge and } \\
\text { creativity }\end{array}$ & 1.4 & 18.5 & $\begin{array}{l}\text { Leisure and } \\
\text { relaxation }\end{array}$ & 1.2 & 26.4 \\
\hline & Believes & 1.1 & 33.9 & $\begin{array}{l}\text { Honesty and } \\
\text { loyalty }\end{array}$ & 0.9 & 40.2 & - & & \\
\hline
\end{tabular}

${ }^{a}$ Factors 4 and 5 are only computed for the values and are displayed in the second row of the category

${ }^{\mathrm{b}} \mathrm{EV}=$ Eigenvalue

split into different categories. As the overview in Table 1 makes clear, almost all the attributes bearing percentages well above 50 per cent, have significantly higher explanatory power than a random classification, which would lead to a 25 per cent correct classification. The only exception is the perceived corporate reputation, which leads to a rate of correct classification of only 46.6 per cent. This can be seen as a first hint that stakeholder groups actually possess heterogeneous attributes, which supports the applicability of some kind of role concept.

As already mentioned, the large number of attributes can create problems in the process of correlating explanatory variables. To avoid this, we performed a main component factor analysis for each category of variables. The Kaiser-Meyer-Olkin (KMO) measure of sampling adequacy is considered a good criterion for testing when data sets are suited to factor analysis (Stewart, 1981; Dzubian and Shirkley, 1974). The results proved that all our data sets fulfill the minimum requirement (Cureton and D'Agostino, 1983) of a
KMO larger than 0.5. The lowest value obtained for the attributes of the value category was 0.7 . The results for the remaining data sets, showing KMOs larger than 0.8, can be labeled as meritorious (Kaiser and Rice, 1974). For all categories of variables, except the values, we extracted three or fewer factors that explain between 45.2 and 65.9 per cent of the entire variance. The results are satisfying and the data output can be used for a consequent discriminant analysis. An overview of categories and extracted factors is displayed in Table 2, while details about factor loadings can be found in Tables A3-A6 in Appendix A.

Factor analysis proved to be an effective method of reducing the number of attributes, because the discriminatory power of the extracted factors was only slightly lower than the full set of characterizing variables. As shown in Table 3, the majority of the correct classifications are less than 10 per cent lower when using factors instead of full sets. The most remarkable difference is that the sum of all discriminating input factors 
Table 3: Results of discriminant analysis with extracted factors

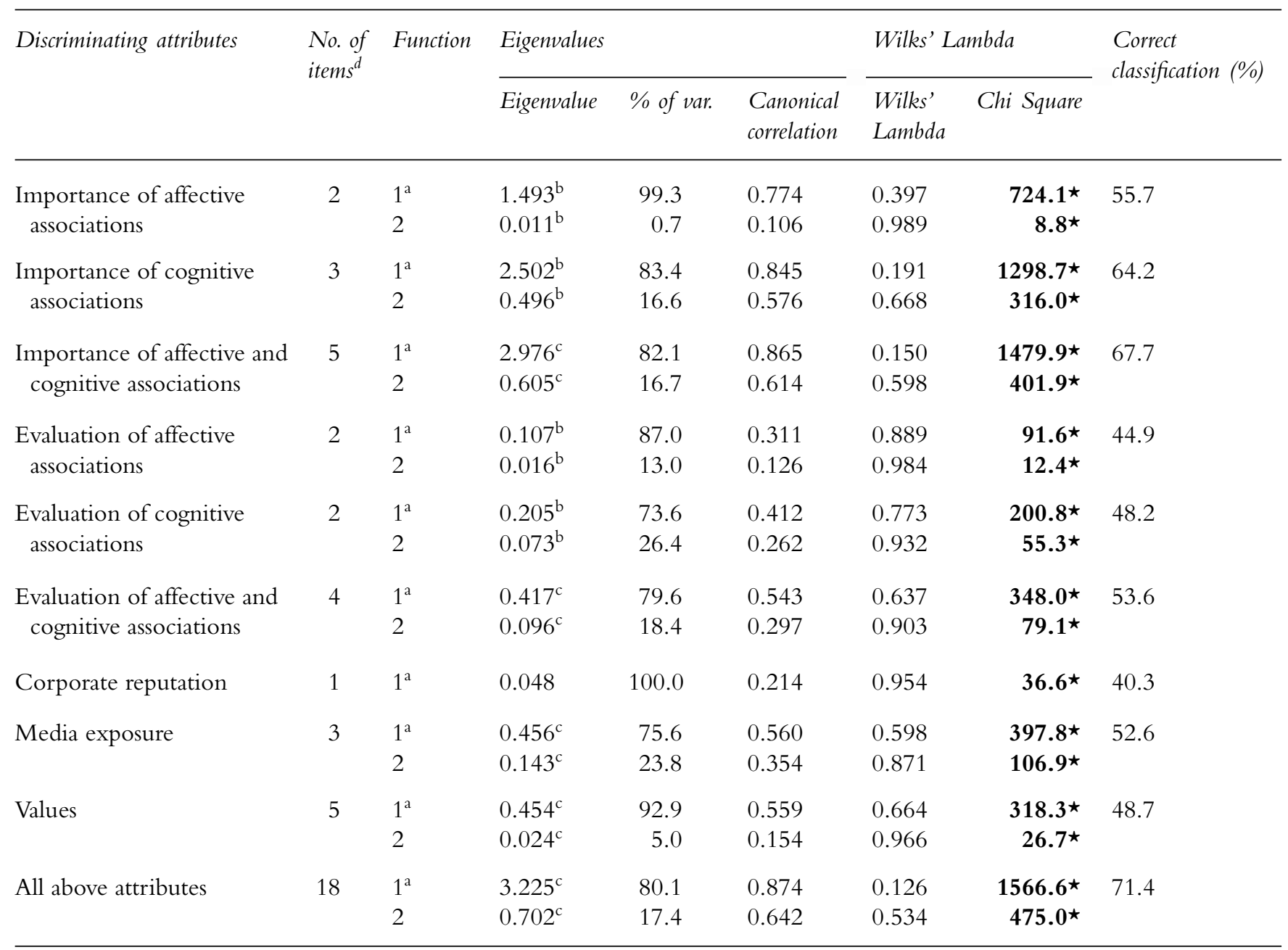

${ }^{a}$ For Wilks' Lambda, this line represents the test of functions 1 to 2

${ }^{b}$ First two canonical discriminant functions were used in the analysis

${ }^{c}$ First three canonical discriminant functions were used in the analysis

${ }^{\mathrm{d}}$ Factors (see Tables A3-A6 in the Appendix A) were used as independent variables of the discriminant function

$\star$ Significant at $1 \%$ level

explains 71.4 per cent when using factors in comparison to 83.0 per cent when using full sets of attributes. These reductions are considered acceptable in avoiding possible violations of assumptions. The overall result is that stakeholder groups show significantly distinct attributes even though the analyzed stakeholder groups are not perfectly differentiated. Consequently, this result offers high support of the role concept.
Our examination of different attributes shows that the classification result of 67.7 per cent correct classification best illustrates the importance of the affective and cognitive associations with corporate brand image, which, in turn, represent stakeholder priorities. The 53.6 per cent correct classification of the actual evaluations of the corporate brand image supports the notion that these attributes are not so different from one group to the next. For 
both categories, importance and evaluation, the cognitive associations are better discriminating indicators. This outcome is in line with the results of the full sets of attributes. Reputation and personal value system, with correct classifications of 40.3 and 48.7 per cent, respectively, do not prove very helpful for discriminating among the stakeholder groups. The 52.6 per cent correct classification using the factors of media exposure for the discriminant function give a weak hint that different stakeholder groups can be approached via different communication channels. The data for the discriminatory power of single factors is displayed in Tables A7 and A8 in the Appendix A.

\section{SUMMARY AND IMPLICATIONS FOR CORPORATE BRANDING}

The results of our research not only support the role concept of stakeholder groups but also suggest that the attributes differ substantially among customers, employees, shareholders and journalists. Even though the discriminating power of group attributes is not perfect, a correct classification of over 80 per cent is possible with their help. This implies that marketing strategies can specifically target single stakeholder groups in order to position a corporate brand accordingly. It is remarkable that not all categories of attributes are equally suitable for a specific approach to the target groups. This leads to the conclusion that some attributes are valuable for the differentiation of the corporate profile among groups while others are helpful for implementing generic associations. This finding supports the concept of addressing micro associations that can be different for the target groups of a corporate brand and meta associations that are congruent over all groups. For the categories of attributes used for discriminating among stakeholder groups, we can summarize the following implications:

- The importance of different aspects of corporate brand image differs more among stakeholders than does the evaluation of these aspects. This implies that stakeholder groups can be approached individually according to their priorities.

- The importance and evaluation of the affective brand associations are less groupspecific than the cognitive associations. The conclusion is that generic positions should be pursued affectively while specifics can be delivered via cognitive marketing approaches, such as knowledgebuilding advertisement strategies.

- Respondents from all four stakeholder groups perceived the reputation of the corporation that we analyzed very similarly. This is consistent with prior expectations about the reputation construct based on stakeholder characteristics.

- Due to identified differences in media exposure, we can address each stakeholder group via distinct communication channels.

- The results show that personal values are not a very good measure for discriminating among stakeholder groups. Generic strategies without specifics aimed at single stakeholder groups are quite adequate when it comes to accommodating personal values.

\section{References}

Aaker, D.A. (2004) 'Leveraging the corporate brand', California Management Review, 46, 6-18.

Aaker, D.A. and Joachimsthaler, E. (2000) Brand Leadership, Free Press, New York.

Aaker, D.A., Kumar, V. and Day, G.S. (2004) Marketing Research, Wiley, New York.

Balmer, J.M.T. (1995) 'Corporate branding and connoisseurship', Journal of General Management, 21, 24-46.

Balmer, J.M.T. (2001) 'Corporate identity, corporate branding and corporate marketing: Seeing through the fog', European Journal of Marketing, 35, 248-291.

Bergstrom, A., Blumenthal, D. and Crothers, S. (2002) 'Why internal branding matters: The case of Saab', Corporate Reputation Review, 5, 133-142.

Berthon, P., Ewing, M.T. and Hah, L.L. (2005) 'Captivating company: Dimensions of attractiveness in employer branding', Journal of Advertising, 24, 151-172. 
Brown, T.J. (1998) 'Corporate associations in marketing: Antecedents and consequences', Corporate Reputation Review, 1, 215-233.

Brown, T.J. and Dacin, P.A. (1997) 'The company and the product: Corporate associations and consumer product responses', Journal of Marketing, 61, 68-84.

Burt, S.L. and Sparks, L. (2002) 'Corporate branding, retailing, and retail internationalization', Corporate Reputation Review, 5, 194-212.

Clarke, T. (1998) 'The Stakeholder Corporation: A business philosophy for the information age', Long Range Planning, 31, 182-194.

Coutu, W. (1951) 'Role-playing vs role-taking: An appeal for clarification', American Sociological Review, 16(2), 180-187.

Cureton, E.E. and D'Agostino, R.B. (1983) Factor Analysis - An Applied Approach, Erlbaum, Hillsdale, NJ.

de Chernatony, L. (2002) 'Would a brand smell any sweeter by a corporate name?' Corporate Reputation Review, 5, 114-132.

de Chernatony, L. and Riley, D.O.F. (1998) 'Defining "Brand": Beyond the literature with experts' interpretations', Journal of Marketing Management, 14, 417-443.

Dzubian, C.D. and Shirkley, E.C. (1974) 'When is a correlation matrix appropriate for factor analysis?' Psychological Bulletin, 81, 358-361.

Fisher, R.A. (1936) 'The use multiple measurements in taxanomic problems', Human Genetics, 7, 179-188.

Fombrun, C.J. and Gardberg, N.A. (2000) 'Who's tops in corporate reputation?' Corporate Reputation Review, 3, 13-17.

Fombrun, C.J. and van Riel, C.B.M. (1997) 'The reputational landscape', Corporate Reputation Review, 1, $5-12$.

Freeman, R.E. (1984) Strategic Management - A Stakeholder Approach, Pitman, Boston.

George, W.R. (1990) 'Internal marketing and organizational behavior: A partnership in developing customer-conscious employees at every level', Journal of Business, 20, 63-70.

Griffin, J.J. (2002) 'To brand or not to brand? Trade-offs in corporate branding decisions', Corporate Reputation Review, 5, 228-240.

Gross, N., Mason, W.S. and McEachern, A.W. (1958) Explorations in Role Analysis, Wiley, New York.

Hägg, C. and Preiholt, H. (2004) 'Investor relations, financial marketing, and target groups', Marketing Management Journal, 14, 129-133.

Harris, F. and de Chernatony, L. (2001) 'Corporate branding and corporate brand performance', European Journal of Marketing, 35, 441-456.

Harrison, J.S. and Freeman, R.E. (1996) 'Stakeholders, social responsibility, and performance: Empirical evidence and theoretical perspectives', Academy of Management Journal, 42, 479-485.

Hermann, S. (2005) Corporate Sustainability Branding Nachhaltigkeits- und stakeholderorientierte Profilierung von Unternehmensmarken, Wiesbaden, DUV.

Jones, T.M. (1995) 'Instrumental stakeholder theory: A synthesis of ethics and economics', Academy of Management Review, 20, 404-437.

Kaiser, H.F. and Rice, J. (1974) 'Little Jiffy, Mark IV', Educational and Psychological Measurement, 34, 111-117.

Keller, K.L. (2003) Strategic Brand Management - Building, Measuring and Managing Brand Equity, PrenticeHall, Upper Saddle River.

Keller, K.L. and Aaker, D.A. (1997) 'Managing the corporate brand: The effects of corporate marketing activity on consumer evaluation of brand extensions', MSI Working Paper Report No. 97-106, MSI Marketing Science Institute, Cambridge, MA.

Lattin, J., Carroll, J.D. and Green, P.E. (2003) Analyzing Multivariate Data, Thomson, Toronto.

Lehmann, D.R., Gupta, S. and Steckel, J.H. (1998) Marketing Research, Addison-Wesley, Reading, MA.

Meffert, H. and Bierwirth, A. (2005) 'Corporate Branding - Führung der Unternehmensmarke im Spannungsfeld unterschiedlicher Zielgruppen', in $\mathrm{H}$. Meffert, C. Burmann and M. Koers (eds.), Markenmanagement - Grundfragen der identitätsorientierten Markenführung, 2nd edn., Gabler, Wiesbaden, pp. 143-162.

Sargent, S. (1951) 'Concepts of role and ego in contemporary psychology', in J.H. Rohrer and M. Sherif (eds.), Social Psychology at the Crossroads, Harper and Brothers, New York, pp. 355-370.

Schultz, M. and de Chernatony, L. (2002) 'The challenges of corporate branding', Corporate Reputation Review, 5, 105-112.

Stewart, D.W. (1981) 'The application and misapplication of factor analysis in marketing research', Journal of Marketing Research, 18, 51-62.

Walker Information Global Network (1999) 'Stakeholder management around the world', in Walker Information Inc. (ed.), Measurements, Walker Information Global Network Stakeholders, Indianapolis.

Walker, S.F. and Marr, J.W. (2001) Stakeholder Power - A Winning Plan for Building Stakeholder Commitment and Driving Corporate Growth, Perseus, Cambridge.

Wiedmann, K.-P. (2002) 'Analyzing the German corporate reputation landscape', Corporate Reputation Review, 4, 337-353.

Winn, M.I. (2001) 'Building stakeholder theory with a decision modelling methodology', Business \& Society, 40, 133-166.

Wolfe, R.A. and Putler, D. (2002) 'How tight are the ties that bind stakeholder groups?' Organization Science, 13, 64-80. 


\section{Appendix A}

See Tables A1-A8.

Table A1: Tests of equality of group means (individual attributes) I

\begin{tabular}{|c|c|c|c|c|c|c|c|c|}
\hline \multicolumn{3}{|c|}{ Importance of affective associations } & \multicolumn{3}{|c|}{ Importance of cognitive associations } & \multicolumn{3}{|c|}{ Evaluation of affective associations } \\
\hline Attributes & $\begin{array}{l}\text { Wilks' } \\
\text { Lambda }\end{array}$ & $F$ & Attributes & $\begin{array}{l}\text { Wilks' } \\
\text { Lambda }\end{array}$ & $F$ & Attributes & $\begin{array}{l}\text { Wilks' } \\
\text { Lambda }\end{array}$ & $F$ \\
\hline Like & 0.672 & $127.2 \star$ & Market position & 0.859 & $43.0^{\star}$ & Like & 0.904 & $27.6^{\star}$ \\
\hline Like you and me & 0.777 & $74.9 \star$ & Image & 0.451 & $318.2^{\star}$ & Like you and me & 0.994 & 1.5 \\
\hline Think positive & 0.374 & $436.9 \star$ & Management quality & 0.655 & $137.8^{\star}$ & Think positive & 0.909 & $25.9 \star$ \\
\hline Attractive & 0.808 & $62.2^{\star}$ & $\mathrm{CEO}$ & 0.783 & $72.4^{\star}$ & Attractive & 0.934 & $18.3 \star$ \\
\hline Different & 0.960 & $10.8 \star$ & Growth potential & 0.645 & $143.6^{\star}$ & Different & 0.882 & $34.6^{\star}$ \\
\hline Consistent & 0.591 & $180.6 \star$ & Social and ethical behavior & 0.654 & $138.1^{\star}$ & Consistent & 0.998 & 0.4 \\
\hline Clear picture & 0.541 & $221.1^{\star}$ & Ecological behavior & 0.653 & $138.6^{\star}$ & Clear picture & 0.926 & $20.7^{\star}$ \\
\hline
\end{tabular}

$\star$ Significant at $1 \%$ level

Table A2: Tests of equality of group means (individual attributes) II

\begin{tabular}{|c|c|c|c|c|c|c|c|c|}
\hline \multicolumn{3}{|c|}{ Evaluation of cognitive associations } & \multicolumn{3}{|l|}{ Media exposure } & \multicolumn{3}{|l|}{ Value system } \\
\hline Attributes & $\begin{array}{l}\text { Wilks' } \\
\text { Lambda }\end{array}$ & $F$ & Attributes & $\begin{array}{l}\text { Wilks' } \\
\text { Lambda }\end{array}$ & $F$ & Attributes & $\begin{array}{l}\text { Wilks' } \\
\text { Lambda }\end{array}$ & $F$ \\
\hline Market position & 0.970 & $8.1^{\star}$ & TV advertising & 0.737 & $92.4^{\star}$ & Higher education & 0.975 & $6.7 \star$ \\
\hline Image & 0.931 & $19.4^{\star}$ & Radio ads & 0.905 & $27.2^{\star}$ & Ecological life & 0.928 & $20.1^{\star}$ \\
\hline Management quality & 0.916 & $23.9 \star$ & Email ads & 0.982 & $4.7 \star$ & New paths & 0.994 & 1.5 \\
\hline $\mathrm{CEO}$ & 0.888 & $32.9 \star$ & Personalized ads via mail & 0.889 & $32.1 \star$ & Living thriftily & 0.870 & $38.9 \star$ \\
\hline Growth potential & 0.902 & $28.3^{\star}$ & Bulk mail & 0.856 & $43.5^{\star}$ & Honesty & 0.994 & 1.6 \\
\hline Social and ethical behavior & 0.990 & 2.7 & Trade fairs & 0.913 & $24.6^{\star}$ & Good outward appearance & 0.953 & $13.0^{\star}$ \\
\hline Ecological behavior & 0.978 & $5.9 \star$ & Homepage & 0.975 & $6.6^{\star}$ & Rest and relaxation & 0.852 & $45.0^{\star}$ \\
\hline$\underline{\text { Reputation }}$ & 0.961 & $10.6^{\star}$ & & & & Loyalty & 0.893 & $31.2^{\star}$ \\
\hline Likeable & 0.958 & $11.3 \star$ & & & & Religious life & 0.994 & $1.5^{\star}$ \\
\hline Trust & 0.990 & 2.6 & & & & & & \\
\hline Quality & 0.887 & $33.3 \star$ & & & & & & \\
\hline Success & 0.928 & $20.3 \star$ & & & & & & \\
\hline
\end{tabular}

* Significant at $1 \%$ level 
Table A3: Factors of individual attributes and factor loadings I

\begin{tabular}{|c|c|c|c|c|c|}
\hline \multicolumn{3}{|c|}{ Importance of affective associations } & \multicolumn{3}{|c|}{ Importance of cognitive associations } \\
\hline Factors & $\begin{array}{l}\text { Liking } \\
\text { and fit }\end{array}$ & $\begin{array}{l}\text { Clear and } \\
\text { different }\end{array}$ & Factors & $\begin{array}{l}\text { Sustainability } \\
\text { and potential }\end{array}$ & Leadership \\
\hline Like & 0.794 & 0.209 & Market position & 0.144 & 0.464 \\
\hline Like you and me & 0.512 & 0.384 & Image & 0.707 & 0.372 \\
\hline Recommended & 0.421 & 0.387 & Quality of products & 0.879 & 0.194 \\
\hline In line with me & 0.668 & 0.372 & Competency of employees & 0.878 & 0.231 \\
\hline Think positive & 0.651 & 0.501 & Management quality & 0.474 & 0.703 \\
\hline Attractive & 0.447 & 0.468 & $\mathrm{CEO}$ & 0.155 & 0.803 \\
\hline Different & 0.137 & 0.520 & Growth potential & 0.153 & 0.810 \\
\hline Consistent & 0.441 & 0.739 & Social and ethical behavior & 0.710 & 0.297 \\
\hline Clear picture & 0.451 & 0.700 & Ecological behavior & 0.729 & 0.252 \\
\hline Close and familiar & 0.485 & 0.601 & Reliability & 0.906 & 0.095 \\
\hline
\end{tabular}

Table A4: Factors of individual attributes and factor loadings II

\begin{tabular}{|c|c|c|c|c|c|}
\hline \multicolumn{3}{|c|}{ Evaluation of affective associations } & \multicolumn{3}{|c|}{ Evaluation of cognitive associations } \\
\hline Factors & $\begin{array}{l}\text { Liking and } \\
\text { fit }\end{array}$ & $\begin{array}{l}\text { Clear and } \\
\text { different }\end{array}$ & Factors & $\begin{array}{l}\text { Sustainability } \\
\text { and potential }\end{array}$ & Leadership \\
\hline Like & 0.817 & 0.251 & Market position & 0.271 & 0.265 \\
\hline Like you and me & 0.565 & 0.276 & Image & 0.690 & 0.293 \\
\hline Recommended & 0.507 & 0.361 & Quality of products & 0.841 & 0.204 \\
\hline In line with me & 0.726 & 0.407 & Competency of employees & 0.622 & 0.249 \\
\hline Think positive & 0.862 & 0.270 & Management quality & 0.286 & 0.838 \\
\hline Attractive & 0.794 & 0.315 & $\mathrm{CEO}$ & 0.143 & 0.874 \\
\hline Different & 0.298 & 0.416 & Growth potential & 0.341 & 0.516 \\
\hline Consistent & 0.218 & 0.578 & Social and ethical behavior & 0.478 & 0.433 \\
\hline Clear picture & 0.170 & 0.681 & Ecological behavior & 0.509 & 0.360 \\
\hline Close and familiar & 0.487 & 0.613 & Reliability & 0.763 & 0.175 \\
\hline
\end{tabular}


Table A5: Factors of individual attributes and factor loadings III

\begin{tabular}{llcc}
\hline Media exposure & & & \\
\hline Factors & Mass media & Specific media & Mail \\
\hline TV advertising & $\mathbf{0 . 6 3 3}$ & -0.012 & 0.163 \\
Radio ads & $\mathbf{0 . 6 6 2}$ & 0.160 & 0.084 \\
Newspaper ads & $\mathbf{0 . 7 1 1}$ & 0.241 & 0.194 \\
Magazine ads & $\mathbf{0 . 6 7 4}$ & 0.284 & 0.214 \\
Email ads & 0.183 & $\mathbf{0 . 4 3 6}$ & 0.301 \\
Personalized ads via mail & 0.134 & 0.282 & $\mathbf{0 . 6 5 6}$ \\
Bulk mail & 0.358 & 0.134 & $\mathbf{0 . 6 2 8}$ \\
Trade fairs & 0.190 & $\mathbf{0 . 6 6 2}$ & 0.173 \\
Homepage & 0.095 & $\mathbf{0 . 5 9 1}$ & 0.209 \\
Sports sponsoring & 0.387 & $\mathbf{0 . 4 7 6}$ & 0.165 \\
Layout of branches & 0.247 & $\mathbf{0 . 3 7 9}$ & 0.186 \\
Public appearance CEO & 0.018 & $\mathbf{0 . 6 2 2}$ & 0.006 \\
\hline
\end{tabular}

Table A6: Factors of individual attributes and factor loadings II

\begin{tabular}{lrrrrr}
\hline Value system & \multicolumn{7}{c}{} & & \\
\hline Factors & $\begin{array}{c}\text { Living } \\
\text { standards }\end{array}$ & $\begin{array}{c}\text { Knowledge and } \\
\text { creativity }\end{array}$ & $\begin{array}{c}\text { Leisure and } \\
\text { relaxation }\end{array}$ & Believes & $\begin{array}{c}\text { Honesty and } \\
\text { loyalty }\end{array}$ \\
\hline Higher education & 0.064 & $\mathbf{0 . 4 6 5}$ & 0.308 & -0.041 & -0.146 \\
Ecological life & -0.260 & 0.262 & 0.309 & $\mathbf{0 . 4 1 5}$ & 0.050 \\
Abundance of leisure time & 0.118 & -0.035 & $\mathbf{0 . 5 8 6}$ & 0.126 & 0.078 \\
High living standard & $\mathbf{0 . 5 0 8}$ & 0.076 & 0.535 & -0.146 & 0.098 \\
New paths & 0.044 & $\mathbf{0 . 4 0 8}$ & -0.029 & 0.039 & 0.168 \\
Living thriftily & 0.022 & 0.026 & 0.156 & $\mathbf{0 . 4 1 5}$ & 0.102 \\
Honesty & -0.092 & 0.182 & 0.092 & 0.102 & $\mathbf{0 . 6 0 6}$ \\
Good outward appearance & $\mathbf{0 . 4 9 6}$ & 0.093 & 0.184 & 0.171 & 0.035 \\
Rest and relaxation & 0.138 & 0.006 & $\mathbf{0 . 4 8 3}$ & 0.299 & 0.320 \\
Consciousness of tradition & 0.336 & -0.015 & 0.141 & $\mathbf{0 . 5 5 7}$ & 0.224 \\
Status symbols & $\mathbf{0 . 7 9 3}$ & 0.016 & 0.037 & 0.106 & -0.013 \\
Striving for knowledge & 0.053 & $\mathbf{0 . 7 3 8}$ & 0.072 & -0.076 & 0.105 \\
Creativity & -0.021 & $\mathbf{0 . 5 1 5}$ & -0.130 & 0.089 & 0.198 \\
Loyalty & 0.190 & 0.218 & 0.125 & 0.176 & $\mathbf{0 . 5 4 1}$ \\
Religious life & 0.085 & -0.034 & -0.079 & $\mathbf{0 . 4 9 6}$ & 0.028
\end{tabular}


Table A7: Tests of equality of group means (factors) I

\begin{tabular}{|c|c|c|c|c|c|c|c|c|}
\hline \multicolumn{3}{|c|}{ Importance of affective associations } & \multicolumn{3}{|c|}{ Importance of cognitive associations } & \multicolumn{3}{|c|}{ Evaluation of affective associations } \\
\hline Attributes & $\begin{array}{l}\text { Wilks' } \\
\text { Lambda }\end{array}$ & $F$ & Attributes & $\begin{array}{l}\text { Wilks' } \\
\text { Lambda }\end{array}$ & $F$ & Attributes & $\begin{array}{l}\text { Wilks' } \\
\text { Lambda }\end{array}$ & $F$ \\
\hline $\begin{array}{l}\text { Factor value } 1 \text { emotional } \\
\text { importance }\end{array}$ & 0.537 & $225.1 \star$ & $\begin{array}{l}\text { Factor value } 1 \text { cognitive } \\
\text { importance }\end{array}$ & 0.288 & $645.4^{\star}$ & $\begin{array}{l}\text { Factor value } 1 \\
\text { emotional evaluation }\end{array}$ & 0.922 & $21.9 \star$ \\
\hline
\end{tabular}

$\star$ Significant at $1 \%$ level

Table A8: Tests of equality of group means (factors) I

\begin{tabular}{|c|c|c|c|c|c|c|c|c|}
\hline Attributes & $\begin{array}{l}\text { Wilks' } \\
\text { Lambda }\end{array}$ & $F$ & Attributes & $\begin{array}{l}\text { Wilks' } \\
\text { Lambda }\end{array}$ & $F$ & Attributes & $\begin{array}{l}\text { Wilks' } \\
\text { Lambda }\end{array}$ & $F$ \\
\hline $\begin{array}{l}\text { Factor value } 1 \text { emotional } \\
\text { evaluation }\end{array}$ & 0.900 & $29.0^{\star}$ & $\begin{array}{l}\text { Factor value } 1 \text { media } \\
\text { exposure }\end{array}$ & 0.786 & $70.3 \star$ & $\begin{array}{l}\text { Factor value } 1 \\
\text { values }\end{array}$ & 0.924 & $21.3 \star$ \\
\hline & & & $\begin{array}{l}\text { Factor value } 3 \text { media } \\
\text { exposure }\end{array}$ & 0.893 & $30.8 \star$ & $\begin{array}{l}\text { Factor value } 3 \\
\text { values }\end{array}$ & 0.780 & $73.4^{\star}$ \\
\hline Corporate reputation & & & & & & $\begin{array}{l}\text { Factor value } 4 \\
\text { values }\end{array}$ & 0.932 & $19.0 \star$ \\
\hline Attributes & $\begin{array}{l}\text { Wilks' } \\
\text { Lambda }\end{array}$ & $F$ & & & & $\begin{array}{l}\text { Factor value } 5 \\
\text { values }\end{array}$ & 0.966 & $9.2^{\star}$ \\
\hline
\end{tabular}

* Significant at $1 \%$ level 